\title{
The Importance of Hematological and Demographic Characteristics in the Course of COVID-19 Pneumonia
}

\section{COVID-19 Pnömonisi Seyrinde Hematolojik ve Demografik Özelliklerin Önemi}

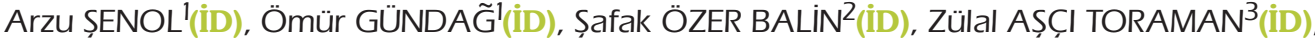 \\ Yeliz GÜL ${ }^{4}$ İD), Ali YILDIRIM ${ }^{5}(\mathrm{ID})$
}

\footnotetext{
${ }^{1}$ Clinic of Infectious Diseases and Clinical Microbiology, Fethi Sekin City Hospital, Elazıg̃, Turkey

${ }^{2}$ Department of Infectious Diseases and Clinical Microbiology, Firat University Faculty of Medicine, Elazı̃̃. Turkey

${ }^{3}$ Division of Clinical Microbiology, Firat University Faculty of Medicine, Elazig̃, Turkey

${ }^{4}$ Clinic of Radiology, Fethi Sekin City Hospital, Elazı̃̃. Turkey

${ }^{5}$ Clinic of Biochemistry, Fethi Sekin City Hospital, Elazı̃̃, Turkey
}

Cite this article as: Şenol A, Gündağ Ö, Özer Balin Ş, Aşçı Toraman Z, Gül Y, Yıldırım A. The importance of hematological and demographic characteristics in the course of COVID-19 pneumonia. FLORA 2021;26(3):460-7.

\begin{abstract}
Introduction: COVID-19 is a rapidly progressive viral disease and early diagnosis is important. We aimed to analyze the hematological parameters that can assist in early detection of severe COVID-19 pneumonia and to determine the significance of demographic characteristics and laboratory parameters in predicting progression to severe disease in mild-to-moderate COVID-19 pneumonia.

Materials and Methods: This study included 336 patients with COVID-19 pneumonia. Patients' demographic data and laboratory findings were obtained retrospectively. The patients were divided into two groups: mild-to-moderate and severe pneumonia.

Results: Of 336, 152 patients had mild-to-moderate and 184 had severe COVID-19 pneumonia. White blood cell, aspartate aminotransferase, fibrinogen, D-dimer, procalcitonin, ferritin, troponin, C-reactive protein levels, systemic inflammatory index, and absolute neutrophil $(N)$ count, as well as $N$-to-lymphocyte $(L)$, monocyte $(M)$-to- $L$, and platelet-to- $L$ ratios were significantly higher in severe pneumonia than mild-to-moderate ones. Albumin level, absolute $L$ and $M$ count, and erythrocyte distribution width were significantly lower in severe pneumonia. The most common comorbidities were hypertension, diabetes, chronic obstructive pulmonary disease.

Conclusion: Findings of this study suggest that some laboratory parameters have prrognostic value in COVID-19 patients are beneficial and frequent follow-ups of selected laboratory parameters can play a key role, especially in patients with comorbidities and advanced age due to the increased risk of severity.
\end{abstract}

Key Words: COVID-19 pneumonia; Hematological parameters; Demographic characteristics; Comorbidities 
ÖZ

\title{
COVID-19 Pnömonisi Seyrinde Hematolojik ve Demografik Özelliklerin Önemi
}

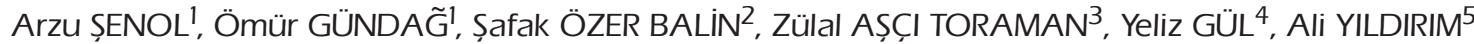 \\ ${ }^{1}$ Fethi Sekin Șehir Hastanesi, İnfeksiyon Hastalıkları ve Klinik Mikrobiyoloji Klinig̃i, Elazı̃̃., Türkiye \\ ${ }^{2}$ Firat Üniversitesi Tip Fakültesi, İnfeksiyon Hastalıkları ve Klinik Mikrobiyoloji Anabilim Dalı, Elazı̃̃g, Türkiye \\ ${ }^{3}$ Firat Üniversitesi Tip Fakültesi, Klinik Mikrobiyoloji Bilim Dalı, Elazı̃̃, Türkiye \\ ${ }^{4}$ Fethi Sekin Șehir Hastanesi, Radyoloji Klinig̃i, Elazı̃̃, Türkiye \\ ${ }^{5}$ Fethi Sekin Șehir Hastanesi, Biyokimya Klinig̃i, Elazı̃̃. Türkiye
}

Giriş: COVID-19 hızla gelişen viral bir hastalıktır ve erken teşhis önemlidir. Şiddetli COVID-19 pnömonisinin erken teşhisine yardıma olabilecek hematolojik parametreleri analiz etmeyi ve hafif orta şiddette COVID-19 pnömonisinde ciddi hastalığa ilerlemeyi öngörmede demografik özelliklerin ve laboratuvar parametrelerinin önemini belirlemeyi amaçladık.

Materyal ve Metod: Bu çalışmaya COVID-19 pnömonisi olan 336 hasta dahil edildi. Hastaların demografik verileri ve laboratuvar bulguları retrospektif olarak elde edildi. Hastalar hafif-orta ve şiddetli pnömoni olmak üzere iki gruba ayrıldı.

Bulgular: 336 hastanın 152'sinde hafif-orta şiddetli, 184'ünde şiddetli COVID-19 pnömonisi vardı. Beyaz kan hücresi, aspartat aminotransferaz, fibrinojen, D-dimer, prokalsitonin, ferritin, troponin, C-reaktif protein seviyeleri, sistemik inflamatuar indeks ve mutlak nötrofil $(N)$ sayısının yanı sıra $N$-lenfosit (L), monosit $(M)$-L ve trombosit-L oranları, şiddetli pnömonide hafif-orta şiddette olanlara göre anlamlı olarak daha yüksekti. Ağır pnömonide albümin düzeyi, mutlak L ve M sayısı ve eritrosit dağılım genişliği anlamlı olarak daha düşüktü. En sık eşlik eden hastalıklar hipertansiyon, diyabet, kronik obstrüktif akciğer hastalığı idi.

Sonuç: Bu çalışmanın bulguları, COVID-19'da prognostik laboratuvar testlerinin faydalı olduğunu ve seçilen laboratuvar parametrelerinin sık takip edilmesinin, artan şiddet riski nedeniyle özellikle komorbiditeli ve ileri yaştaki hastalarda önemli bir rol oynayabileceğini düşündürmektedir.

Anahtar Kelimeler: COVID-19 pnömonisi; Hematolojik parametreler; Demografik özellikler; Komorbiditeler

\section{INTRODUCTION}

In early December 2019, an ongoing outbreak of novel coronavirus disease 2019 (COVID-19)-induced pneumonia was first identified in Wuhan, China ${ }^{[1]}$. COVID-19 is caused by severe acute respiratory syndrome coronavirus 2 (SARSCoV-2); the virus is spreads rapidly, infecting millions of people and resulting in many deaths worldwide $^{[2,3]}$. A long incubation period and high infection rates increase COVID-19 transmission ${ }^{[4]}$. SARS-CoV-2, a member of the Betacoronavirus genus of the Coronaviridae family, is an enveloped, positive single-stranded ribonucleic acid virus ${ }^{[2]}$. Upon entering the patient through the nasal and pharyngeal mucous membranes, SARS-CoV-2 virions settle in the lungs via respiration and in the heart, kidneys, lungs, gastrointestinal system, and vascular endothelial cells with their viremia ${ }^{[5]}$.

The virus is transmitted through direct contacts or small droplets. Asymptomatic infection can lead to mild upper respiratory tract symp- toms, severe pneumonia that may require admission to the intensive care unit, adult respiratory distress syndrome, diffuse intravascular coagulation, sepsis, organ failure, and even death. While the most common symptoms of COVID-19 are fever, cough, fatigue, pain, dyspnea, hemoptysis, and diarrhea, other symptoms such as myalgia, headache, and loss of sense of taste and smell have also been reported ${ }^{[5,6]}$. COVID-19-related morbidity and mortality have been associated with advanced age, male gender, and comorbid diseases $^{[1]}$. On computed tomography (CT), bilateral pneumonia or ground-glass opacity is generally observed in the lungs ${ }^{[7]}$.

The severity of the disease in patients with COVID-19 could be attributed to the exaggerated immune response due to SARS-CoV-2 infection leading to an inflammatory cytokine storm, which eventually results in acute respiratory distress syndrome and multi-organ failure ${ }^{[8]}$. Considering the high rates of morbidity and mortality associated 
with the disease, both early diagnosis and determination of demographic and laboratory factors predicting prognosis are crucial. In severe COVID-19 pneumonia, hematological and biochemical parameters may be indicators of early inflammation ${ }^{[1,8,9]}$. This study aimed to analyze the hematological parameters that can assist in the early detection of severe COVID-19 pneumonia and to determine the significance of demographic characteristics and laboratory parameters in predicting in severe and mild-to-moderate COVID-19 pneumonia.

\section{MATERIALS and METHODS}

\section{Study Design, Participants, and Data Collection}

This retrospective study included 336 patients diagnosed with COVID-19 pneumonia who were hospitalized between April 2020 and November 2020. Patients' demographic characteristics, medical history, laboratory, and radiological findings (real-time RT-PCR test of nasopharyngeal swab samples) were retrospectively obtained from electronic medical records.

According to the COVID-19 pneumonia diagnosis and treatment program of the Ministry of Health, patients were classified into two groups: those with mild-to-moderate pneumonia and those with severe pneumonia. As per the clinical classification criteria, patients with mild-to-moderate COVID-19 pneumonia have mild lung involvement on thorax CT, resting oxygen saturation $\geq 90 \%$, respiratory rate $<30$ breaths $/ \mathrm{min}$, with a mask or nasal cannula with or without oxygen, and arterial partial pressure of oxygen $\left(\mathrm{PaO}_{2}\right) /$ inspired oxygen fraction $\left(\mathrm{FiO}_{2}\right)>300 \mathrm{mmHg}$. Patients with severe pneumonia have widespread involvement on thorax CT, tachypnea or orthopnea with resting oxygen saturation of $\leq 90 \%$, respiratory rate $\geq 30$ breaths $/ \mathrm{min}$, and oxygenation index $\mathrm{PaO}_{2} / \mathrm{FiO}_{2} \leq 300 \mathrm{mmHg}$, and receive oxygen therapy with a reservoir mask or continuous positive airway pressure device ${ }^{[10]}$.

Hematological; white blood cell count (WBC), hematocrit (Hct), absolute neutrophil count (ANC), absolute lymphocyte count (ALS), absolute monocyte count (AMS), mean platelet volume (MPV), erythrocyte distribution width (RDW), neutrophil/ lymphocyte ratio (NLR), platelet/lymphocyte ra- tio (PLR), monocyte/lymphocyte ratio (MLR) and biochemical; alanine aminotransferase (ALT), aspartate aminotransferase (AST), total bilirubin, creatinine, creatinine kinase $(\mathrm{CK})$, procalcitonin, ferritin, troponin, albumin, coagulation (fibrinogen, D-dimer), erythrocyte sedimentation rate (ESR), $C$ reactive protein (CRP) were part of routine blood analysis in COVID-19 cases. In addition, the systemic inflammatory index (SII) score was calculated in addition to the available data ${ }^{[11]}$.

$\mathrm{SII}=$ platelet count $\mathrm{x}$ neutrophil count/lymphocyte count,

$\mathrm{NLR}=$ absolute neutrophil count/absolute lymphocyte count,

$\mathrm{PLR}=$ absolute PLT/absolute lymphocyte count formulas were used.

Real-time PCR (RT-PCR) analyzes were performed in Inonu and Firat University Hospital Medical Microbiology Laboratories. Those under the age of 18 had clinical findings and/or pneumonia findings consistent with COVID-19 in Thorax CT, and cases negative for RT-PCR test were excluded from the study. The study protocol complied with the Helsinki Declaration of ethics and the study was approved by the University Clinical Research Ethics Committee with the decision dated 17.09.2020 and numbered 2020/12-15.

\section{RESULTS}

Of the mild-to-moderate pneumonia cases, 86 were men and 66 were women (age range $52.7 \pm 2.1$ ). Of the patients with severe pneumonia, 103 were men and 81 were women (age range $67.9 \pm 1.6$ ). Mild-to-moderate and severe pneumonia was mostly detected in male gender, but there was no statistically significant difference between the two groups in terms of gender ( $p>0.05)$. The mean age of the patients with severe pneumonia was higher and this was statistically significant (p: 0.001). WBC, AST, ALT, CK, creatinine, fibrinogen, D-dimer, procalcitonin, ferritin, troponin, CRP, ESR levels, SII, MNS, NLR, MLR, PLR were higher in severe pneumonia than mild-to-moderate ones and were statistically significant $(p<0.05)$.

Albumin levels, Hct, MLS, MMS and RDW were statistically significantly lower in patients with 
severe pneumonia $(p<0.05)$. MPV level was found to be slightly increased in severe pneumonia cases, but it was not statistically significant ( $p>0.05$ ). No statistically significant difference was observed between the cases with mild-to-moderate and severe pneumonia in terms of platelet levels ( $p$ : 0.140). PTT was longer in patients with severe pneumonia, but this was not statistically significant ( $p>0.05$ ). Demographic data and laboratory parameters of patients with COVID-19 mild-to-moderate and severe pneumonia are presented in Table 1.
While all cases with mild-to-moderate pneumonia were discharged, 73 cases followed in the ICU with severe pneumonia died (39.7\%). While the most common complaints in patients with severe pneumonia were dyspnea (45.6\%), fatigue (11.9\%), fever (11.9\%), muscle-joint pain $(8.7 \%)$, the most common complaints in patients with mild pneumonia were; Cough (21.7\%), fatigue (17.8\%), fever (13.2\%), shortness of breath $(12.5 \%)$. Symptoms seen in patients with COVID-19 mild-to-moderate and severe pneumonia

\begin{tabular}{|c|c|c|c|}
\hline & Mild-moderate pneumonia & Severe pneumonia & $p$ \\
\hline Sex (male/female) & $86 / 66$ & $103 / 81$ & 0.186 \\
\hline Age (year) & $52.7 \pm 2.1(18-87)$ & $68.0 \pm 1.6(19-96)$ & 0.001 \\
\hline WBC $\left(10^{9} / \mathrm{L}\right)$ & $6482.9 \pm 283.7$ & $8814.1 \pm 438.4$ & 0.001 \\
\hline AST (U/L) & $32.8 \pm 1.6$ & $48.1 \pm 3.1$ & 0.001 \\
\hline $\operatorname{ALT}(\mathrm{U} / \mathrm{L})$ & $29.3 \pm 3.1$ & $34.0 \pm 3.1$ & 0.118 \\
\hline CK (IU/L) & $141.7 \pm 18.1$ & $312.0 \pm 58.4$ & 0.008 \\
\hline Platelet count $\left(\times 10^{9} / \mathrm{L}\right)$ & $206470 \pm 7724.9$ & $221390 \pm 9558.1$ & 0.140 \\
\hline PT (sec) & $12.2 \pm 0.6$ & $13.7 \pm 0.5$ & 0.090 \\
\hline Creatinine (mg/dL) & $0.9 \pm 0.1$ & $1.2 \pm 0.1$ & 0.043 \\
\hline Albumin ( $g / L)$ & $40.1 \pm 0.5$ & $32.8 \pm 0.5$ & 0.001 \\
\hline Fibrinogen (g/L) & $3.8 \pm 0.3$ & $6.3 \pm 0.3$ & 0.001 \\
\hline D-dimer $(\mu \mathrm{g} / \mathrm{mL})$ & $788.3 \pm 126.1$ & $2927.0 \pm 629.6$ & 0.001 \\
\hline SII & $568.5 \pm 43.5$ & $2439.0 \pm 295.1$ & 0.001 \\
\hline Procalcitonin $(\mu \mathrm{g} / \mathrm{L})$ & $0.07 \pm 0.017$ & $0.7 \pm 0.14$ & 0.003 \\
\hline Ferritin $(\mu \mathrm{g} / \mathrm{L})$ & $152.8 \pm 18.5$ & $418.9 \pm 37.8$ & 0.001 \\
\hline Troponin (ng/L) & $8.05 \pm 1.7$ & $118.7 \pm 81.8$ & 0.002 \\
\hline Neutrophil count $\left(\times 10^{9} / \mathrm{L}\right)$ & $3.9 \pm 0.2$ & $7.1 \pm 0.3$ & 0.001 \\
\hline Lymphocyte count $\left(\times 10^{9} / \mathrm{L}\right)$ & $1.7 \pm 0.1$ & $1.0 \pm 0.1$ & 0.001 \\
\hline Monocyte count $\left(\times 10^{9} / \mathrm{L}\right)$ & $0.7 \pm 0.1$ & $0.6 \pm 0.1$ & 0.004 \\
\hline НСТ (\%) & $41.1 \pm 0.6$ & $38.9 \pm 0.6$ & 0.004 \\
\hline NLR & $2.9 \pm 0.2$ & $10.4 \pm 1.1$ & 0.001 \\
\hline MLR & $0.5 \pm 0.04$ & $0.7 \pm 0.1$ & 0.001 \\
\hline PLR & $148.0 \pm 10.5$ & $287.8 \pm 19.1$ & 0.001 \\
\hline MPV (fL) & $8.3 \pm 0.1$ & $8.3 \pm 0.1$ & 0.090 \\
\hline RDW (\%) & $15.8 \pm 1.7$ & $14.8 \pm 0.2$ & 0.009 \\
\hline CRP (mg/L) & $20.8 \pm 3.0$ & $114.2 \pm 9.3$ & 0.001 \\
\hline $\operatorname{ESR}(\mathrm{mm} / \mathrm{h})$ & $22.3 \pm 3.4$ & $40.3 \pm 3.7$ & 0.040 \\
\hline
\end{tabular}

HCT: Hematocrit, MPV: Mean platelet volume, RDW: Erythrocyte distribution width, NLR: Neutrophil/lymphocyte ratio, PLR: Platelet/ lymphocyte ratio, MLR: Monocyte/lymphocyte ratio, ALT: Alanine aminotransferase, AST: Aspartate aminotransferase, CK: Creatinine kinase, ESR: Erythrocyte sedimentation rate, CRP: C reactive protein, SII: Systemic inflammatory index, PT: Protrombin time. 
Table 2. Symptoms seen in patients with severe and mild pneumonia Severe pneumonia ( $\mathrm{n}: 184) \mathrm{n}(\%)$ Mild-moderate pneumonia (n: 152) n (\%)

\begin{tabular}{lcc}
\hline Shortness of breath & $84(45.65)$ & $19(12.5)$ \\
Fatigue & $22(11.95)$ & $27(17.76)$ \\
Fever & $22(11.95)$ & $20(13.16)$ \\
Muscle-joint pain & $16(8.70)$ & $16(10.53)$ \\
Cough & $11(5.98)$ & $33(21.71)$ \\
Anorexia & $9(4.89)$ & $8(5.26)$ \\
Headache & $5(2.72)$ & $10(6.58)$ \\
Chest pain & $3(1.63)$ & $1(0.66)$ \\
Sputum & $3(1.63)$ & $2(1.32)$ \\
Diarrhea & $3(1.63)$ & $3(1.97)$ \\
Throat ache & $2(1.09)$ & $5(3.29)$ \\
Nausea and vomiting & $2(1.09)$ & $8(5.26)$ \\
Dizziness & $2(1.09)$ & -
\end{tabular}

are given in Table 2. Forty-four of the cases with mild-moderate pneumonia and 109 of the cases with severe pneumonia had comorbid diseases.

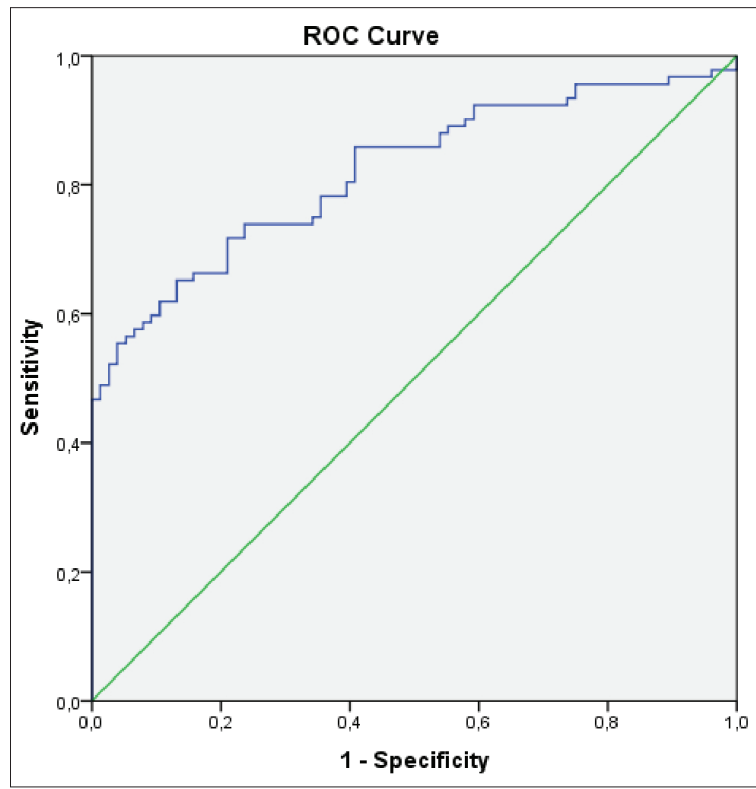

Figure 1. Receiver operating characteristic curves for systemic inflammatory index.
The most common comorbid diseases in patients with mild-moderate and severe pneumonia are hypertension (17.1\%, 66.7\%, respectively), diabetes mellitus (DM) (9.2\%, 29.7\%, respectively), chronic obstructive pulmonary disease (COPD) (5.3\%, 16.5\%, respectively) and cardiovascular disease (5.3\%, 11\%, respectively).

Based on the ROC curve, the area under the curve (AUC) for the systemic inflammatory index in predicting disease severity in COVID-19 patients was $0.820(p=0.000)$ (Figure 1, Table 3 ). According to the results of the likelihood ratio test, the cut-off value for SII was 1447 (sensitivity $55.4 \%$ and specificity 96\%).

\section{DISCUSSION}

COVID-19 is a rapidly developing viral disease and early diagnosis is important ${ }^{[2]}$. Thus, accurate and timely prognostic evaluation is required to improve patient management ${ }^{[12]}$. Studies have reported a relationship between male gender and severe pneumonia ${ }^{[13,14]}$. In a study, it was emphasized that the risk factors contributing to

Table 3. AUC and cut-off values for the systemic inflammatory index in predicting disease severity in COVID-19 patients

\begin{tabular}{lccccccc} 
& AUC & Cut-off value & Sensitivity & Specificity & $95 \% \mathrm{Cl}$ & $\mathbf{p}$ \\
\hline SII & 0.820 & 1447 & 0.554 & 0.960 & $0.757-0.883$ & 0.000 \\
\hline SII: Systemic inflammatory index. & & & & &
\end{tabular}


serious disease in COVID-19 pneumonia are male gender, together with comorbidities such as advanced age, hypertension, and $\mathrm{DM}^{[6]}$. Baloch et al. ${ }^{[15]}$ found that severe prognosis is more common especially in older men.

Ghweil et al. ${ }^{[16]}$ identified DM, hypertension, and ischemic heart disease as the most common chronic diseases among the comorbidities associated with COVID-19. In our study, comorbidities were found in 44 cases with mild-tomoderate pneumonia and 109 cases with severe pneumonia. The most common comorbidities were hypertension $(17.1 \%, 66.7 \%$, respectively), diabetes mellitus (DM) (9.2\%, 29.7\%, respectively), chronic obstructive pulmonary disease (COPD) (5.3\%, 16.5\%, respectively) and cardiovascular disease $(5.3 \%, 11 \%$, respectively), and the vast majority of our patients were male. The mean age of our patients with severe pneumonia was significantly higher.

In a study neutrophilia, lymphopenia, thrombocytopenia, increased CRP, procalcitonin, D-dimer, lactate, liver enzyme levels and decreased renal function values and the presence of hypercoagulation in patients who need to be hospitalized in the ICU have been determined to be demonstrative parameters ${ }^{[6]}$. The patients with severe COVID-19 have lower MLS and percentages and higher WBC and neutrophil levels ${ }^{[7]}$. In another study, lymphopenia, high CRP, ESR and ferritin were found to be associated with COVID-19[16]. In a study, it was suggested that the decrease in MLS and the use of NLR could be a biomarker for early diagnosis ${ }^{[17]}$. A study found that patients hospitalized with COVID-19 had higher WBC and MNS as well as lower MLS in those with severe symptoms ${ }^{[18]}$.

It has been shown that lymphopenia, leukocytosis, increased ANC as well as CRP, procalcitonin, ESR, ferritin, and NLR are the most common findings observed during the progression from mild-to-moderate to critical state and are positively associated with disease severity ${ }^{[19]}$. In meta-analysis related to the COVID-19 outbreak, high ESR, CRP, ferritin, and procalcitonin were observed among severe patients with COVID-19[3]. Gong et al. ${ }^{[20]}$ reported that higher serum CRP, direct bilirubin and creatinine levels, and lower albumin were associated with severe disease and disease progression. In our study, consistent with all these studies, WBC, procalcitonin, ferritin, CRP, ESR levels, MNS, NLR were found to be statistically higher in patients with severe pneumonia compared to patients with mild-tomoderate pneumonia.

Chen et al. ${ }^{[21]}$ reported that liver function tests were significantly higher in severe cases compared to mild cases. In addition, in critically ill patients, it was observed that total bilirubin, blood urea nitrogen (BUN) and creatinine increased in addition to elevation of CK, AST and ALT ${ }^{[6]}$. In our study, in accordance with the studies, it was found that AST, ALT, CK and creatinine levels were higher in cases with severe pneumonia than cases with mild-to-moderate pneumonia. Albumin levels were found to be low in severe patients ${ }^{[19]}$. It has been reported that low serum albumin levels are significantly associated with the severity of COVID-19, and it has been emphasized that albumin levels tend to decrease during disease progression ${ }^{[6,16]}$. In this study, it is noteworthy that serum albumin levels were lower in patients with severe pneumonia. High troponin levels in COVID-19 patients have been reported as a risk factor for severe pneumonia cases, and an increase in cardiac troponin levels has been found in 7-20\% of severe cases ${ }^{[5,22]}$. In this study, troponin levels were higher in patients with severe pneumonia.

Lippi et al. ${ }^{[23]}$ showed that patients with severe symptoms had lower hemoglobin and Hct levels than those with mild symptoms. In COVID-19 patients with severe disease, MPV was higher, while platelet count, hemoglobin and Hct levels were lower, MPV was found to be significantly higher in severe cases than in mild cases ${ }^{[7]}$. In our study, MPV levels were higher in patients with severe pneumonia, although the difference was not statistically significant; however, hematocrit levels in patients with severe penumonia were significantly lower. A study involving 1,099 patients found that $57.5 \%$ of patients in the ICU have thrombocytopenia ${ }^{[2]}$. Lippi et al. ${ }^{[24]}$ reported significant thrombocytopenia in patients with severe COVID-19 and that thrombocytopenia can be evaluated as an indicator during the progression 
of the disease. It has been reported that there was a significant increase in D-dimer levels in patients with severe disease ${ }^{[2,25]}$. Increased D-dimer levels are associated with poor prognosis in patients infected with COVID-19[2]. Available data show that patients with severe COVID-19 often have high D-dimer levels $(46.4 \%)^{[22]}$. Patients with severe COVID-19 have thrombocytopenia and higher D-dimer levels, as well as prolonged PTT values $^{[4]}$. Gao et al. ${ }^{[26]}$ significantly correlated D-dimer and fibrinogen values with the severity of the disease and suggested that higher D-dimer levels were early predictors of disease severity. Hyperfibrinogenemia, is common in the early phase of COVID-19. Hypofibrinogenemia may be observed in the late stage of consumption coagulopathy; thus, fibrinogen levels may have the potential to guide evaluate prognosis ${ }^{[4,19]}$. In our study, no significant difference was observed between mild-to-moderate and severe pneumoniae cases in terms of platelet levels but, D-dimer and fibrinogen levels were found to be higher in patients with severe pneumonia. PTT was higher in cases with severe compared to mild-tomoderate cases.

A recently proposed prognostic score is SII based on platelets, neutrophils, and lymphocytes. As an index defining instability in the inflammatory response, SII has been proposed as a prognostic indicator in the follow-up of patients with sepsis. In one study, it was reported that SII was significantly higher in COVID-19 patients and could be used in the diagnosis of COVID-19 ${ }^{[8]}$. High NLR and high SII were observed in critically ill patients who had to be hospitalized in the ICU $^{[22]}$. In the current study, SII was found to be statistically significantly higher in cases with severe pneumonia than in cases with mild pneumonia.

Lagadinou $\mathrm{M}$ et al. ${ }^{[27]}$, while fatigue, dry cough, and anorexia were observed in more than half of patients with COVID-19 pneumonia, dyspnea was detected in all the severe cases and only $12.5 \%$ of mild cases. Guan et al. ${ }^{[2]}$ observed fever, cough, and less frequently, nausea, vomiting, and diarrhea in their study. In our study, the most common complaint was found to be dyspnea in patients with severe pneumonia, while dyspnea was reported less frequently in mild-to-moderate cases $(45.6 \%$ and $12.5 \%$, respectively).

The limitations of this study are its relatively small sample size and the fact that it is a single center study. Studies involving more centers and larger patient series may be beneficial.

The most effective step for patient management in COVID-19 disease, which does not currently have a specific treatment, is to predict a serious course early; this may contribute to reducing the risk of complications and mortality. Thus, prognostic laboratory tests in COVID-19 may be of great importance. In addition to the diagnostic benefit of these parameters, they are useful in distinguishing mild-to-moderate and severe pneumonia cases as well as in monitoring progression and prognosis. Therefore, we think that frequent follow-up of selected laboratory parameters will play a key role, especially in patients with comorbid diseases and advanced age, due to the increased risk of a severe course.

\section{Acknowledgements}

For his contributions, Thanks to Op. Dr. Sefa Şenol.

\section{ETHICS COMMITTEE APPROVAL}

This study was obtained from Firat University Non-invasive Researches Ethics Committee (Decision No: 2020/12-15, Date: 17.09.2020).

\section{CONFLICT of INTEREST}

None of the authors had conflict of interest.

\section{AUTHORSHIP CONTRIBUTIONS}

Concept and Design: AȘ, ÖG

Data Collection or Processing: AȘ, SB

Analysis/Interpretation: AȘ, ÖG

Literature Search: AȘ, ȘB

Writing: AȘ, ŞB, ÖG

Final Approval: All of authors

\section{REFERENCES}

1. Salamanna F, Maglio M, Landini MP, Fini M. Platelet functions and activities as potential hematologic parameters related to Coronavirus Disease 2019 (Covid-19). Platelets 2020;31(5):627-32. 
2. Słomka A, Kowalewski M, Zekanowska W. Coronavirus Disease 2019 (COVID-19): A short review on hematological manifestations. Pathogens 2020;9:493.

3. Elshazli RM, Toraih EA, Elgaml A, El-Mowafy M, El-Mesery $M$, Amin $M N$, et al. Diagnostic and prognostic value of hematological and immunological markers in COVID-19 infection: A meta-analysis of 6320 patients. PLOS ONE 2020;15(8):e0238160.

4. Luo L, Xu M, Du M, Kou H, Liao D, Cheng Z, et al. Early coagulation tests predict risk stratification and prognosis of COVID-19. Aging 2020;12(16):15918-37.

5. Ricardo DO, Cruz ARJ. Coronavirus Disease 2019: Hematological Anomalies and Antithrombotic Therapy. Tohoku J Exp Med 2020;251:327-36.

6. Tjendra Y, Al Mana AF, Espejo AP, Akgün Y, Millan NC, Fernandez CG, et al. Predicting Disease Severity and Outcome in COVID-19 Patients: A Review of Multiple Biomarkers. Arch Pathol Lab Med 2020;144(12):1465-74.

7. Wu Y, Huang X, Sun J, Xie T, Lei Y, Muhammad J, et al. Clinical Characteristics and Immune Injury Mechanisms in 71 Patients with COVID-19. mSphere 2020;5(4):00362-20.

8. Usul E, San I, Bekgoz B, Sahin A. The role of hematological parameters in COVID-19 patients in the emergency room. Biomarkers Med 2020;317:1-9.

9. Henry BM, Benoit JL, Benoit S, Pulvino C, Berger BA, Olivera MHS, et al. Red Blood Cell Distribution Width (RDW) Predicts COVID-19 severity: A prospective, observational study from the Cincinnati SARS-CoV-2 emergency department cohort. Diagnostics 2020;10:618

10. TR Ministry of Health 2020 COVID-19 (SARS-CoV-2 infection) Adult patient treatment at: https://covid19.saglik.gov. tr Accessed date: September 9, 2020.

11. Liu J, Li S, Zhang S, Liu Y, Ma L, Zhu J, et al. Systemic immune-inflammation index, neutrophil-to-lymphocyte ratio, platelet-to-lymphocyte ratio can predict clinical outcomes in patients with metastatic non-small-cell lung cancer treated with nivolumab. J Clin Lab Anal 2019;33(8):e22964.

12. Ding $X, Y u Y, L u B, H u$ J, Chen $M$, Kang $Y$, et al. Dynamic profile and clinical implications of hematological parameters in hospitalized patients with coronavirus disease 2019. Clin Chem Lab Med 2020;58(8):1365-71.

13. Lusignan D, Dorward SI, Correa A, Jones N, Akinyemi O, Amirthalingam $G$, et al. Risk factors for SARS-CoV-2 among patients in the Oxford Royal College of General practitioners research and surveillance centre primary care network: $A$ cross-sectional study. Lancet Infect Dis 2020;20(9):1034-42.

14. Dangis A, Brucker DN, Heremans A, Gillis M, Frans J, Demeyere $A$, et al. Impact of Gender on Extent of Lung Injury in COVID-19. Clin Radiol 2020;75:554-6.

15. Baloch S, Baloch MA, Zheng T, Pei X. The coronavirus disease 2019 (COVID-19) pandemic. Tohoku / Exp Med 2020;250:271-8.

16. Ghweil AA, Hassan MH, Khodeary A, Mohamed AO, Mohamed HM, Abdelezez AA, et al. Characteristics, outcomes and indicators of severity for COVID-19 among sample of ESNA quarantine hospital's patients, Egypt: A retrospective study. Infect Drug Resist 2020;13:2375-83.
17. Kermali M, Khalsa RK, Pillai K, Ismail Z, Harky A. The role of biomarkers in diagnosis of COVID-19 - A systematic review. Life Sci 2020;254:117788.

18. Wang D, Hu B, Hu C, Zhu F, Liu X, Zhang J, et al. clinical characteristics of 138 hospitalized patients with 2019 novel coronavirus-infected pneumonia in Wuhan, China. JAMA 2020;323:1061-9.

19. Yuan X, Huang $W$, Ye B, Chen $C$, Huang $R$, Wu F, et al. Changes of hematological and immunological parameters in COVID 19 patients. Int J Hematol 2020;2:1-7.

20. Gong J, Ou J, Qiu X, Jie Y, Chen Y, Yuan L, et al. A tool to early predict severe corona virus disease 2019 (COVID-19): a multicenter study using the risk nomogram in Wuhan and Guangdong, China. Clin Infect Dis 2020;71(15):833-40.

21. Chen G, Wu D, Guo W, Cao Y, Huang D, Wang H, et al. Clinical and immunological features of severe and moderate coronavirus disease 2019. J Clin Invest 2020;130(5):2620-9.

22. Wang X, Du B, Li J, Wang S, Wang X, Guo MY, et al. D-dimer surge and coagulation disorders in COVID-19 related pneumonia patients with cardiac injury A case series. Medicine 2020;99(31):e21513.

23. Lippi G, Mattiuzzi C. Hemoglobin value may be decreased in patients with severe Coronavirus Disease 2019. Hematol Transfus Cell Ther 2020;42:116-7.

24. Lippi G, Plebani M, and Henry BM. Thrombocytopenia is associated with severe coronavirus disease 2019 (COVID-19) infections: A meta-analysis. Clinica Chimica Acta 2020;506:45-148.

25. Lippi G, Favaloro EJ. D-dimer Is associated with severity of Coronavirus Disease 2019: a pooled analysis. Thromb Haemost 2020;120:876-8.

26. Gao $Y, L i T$, Han $M, L i X, W u D, X u Y$, et al. Diagnostic utility of clinical laboratory data determinations for patients with the severe COVID-19. J Med Virol 2020;92:791-6.

27. Lagadinou $M$, Solomou EE, Zareifopoulos $N$, Marangos $M$, Gogos C, Velissaris D. Medicina Prognosis of COVID-19: Changes in laboratory parameters. Le Infezioni in Medicina 2020;1:89-95.

28. Guan GW, Gao L, Wang IW, Wen XI, Mao TH, Peng SW, et al. Exploring the mechanism of liver enzyme abnormalities in patients with novel coronavirus-infected pneumonia. Zhonghua Gan Zang Bing Za Zhi 2020;28(2):100-6.

\section{Address for Correspondence/Yazıșma Adresi}

Dr. Arzu ȘENOL

Fethi Sekin Şehir Hastanesi,

İnfeksiyon Hastalıkları ve

Klinik Mikrobiyoloji Kliniği,

Elazığ-Türkiye

E-posta: asenol2017@gmail.com 